\title{
Can Religious States and Representations Be Religious and Secular? A Critique of the Psychology of Religion
}

DOI: https://doi.org/10.22394/2311-3448-2019-6-1-44-64

Vladimir Mikheev - Higher School of Economics (Moscow, Russia).Dezem@bk.ru

Since the 1990s, there has been an ongoing discussion in religious studies about the uses of the terms "secular" and "religious." This article applies the methodology of the critical study of religion within the psychology of religion. There are two main strategies to construct a research program in this field: (1) studying how religious senses occur (neurotheology, transpersonal psychology) and (2) studying how religious representations emerge (cognitive religious studies). This paper provides an overview of these two paradigms through the lens of the religious/secular dichotomy. Scholars who are trying to understand the nature of religious phenomena ignore a significant amount of data labeled as "secular." The author then suggests studying such representations or senses beyond the religious/secular dichotomy.

Keywords: cognitive religious studies, ideological critique of religious studies, intuitive representations, neurotheology, protected values, religious representation, religious experience.

HE word "religion" is quite common in law, in the media, and in academic and everyday speech. However, this term is inter-

1 preted in ways that are contradictory and vague. This leads to discriminatory policy, negative or affirmative, toward certain groups based on their religiousness. ${ }^{1}$ The appropriateness of this term was questioned in the 1990 s by a group of scholars who developed what

1. Kenny provides the examples of jurisprudential cases from the European court. See Kenny 2014. 
became known as "the ideological critique of religious studies." 2 In November 2012 this way of thought became institutionalized: scholars from University of Stirling (Scotland) organized the international "Critical Religion Association." Ivan Stransky, William Cavanaugh, Talal Asad, and Timothy Fitzgerald are leading authors of this field. Anthropologists and religious scholars, including Russians, actively discuss issues raised by this group (Forum 2017).

Their idea was to encounter Religious Studies as a research project that had its own history and ambitions. How did religious scholars create their field of investigation, how did ideologies ${ }^{3}$ use the term "religion," and what kind of biases does the field of Religious Studies create? These critics were inspired by critical sociology (Michel Foucault, Edward Said, Lawrence Newman) and Thomas Kuhn's paradigm shift theory (Strenski 2004). They claim that scientific knowledge is useful not merely for scientific discoveries, but also to legitimize power constellations in society (Asad 2003).

Each author came to his own conclusions in a different way. Church historian Cavanaugh traced the transformation of the term religio from Ancient Rome to the present and how it became common in Western culture. Asad, a historian of Muslim culture, studied the rise of the term "secular" and the exploitation of this term by the colonial authorities to create an Orientalized image of the Eastern world. During his anthropological research in Japan and India, Fitzgerald realized the impossibility of distinguishing "religious" from "non-religious" practices and institutions (Asad 2003; Cavanaugh 2009; Fitzgerald 2003). Each of these authors concluded that the terms "secular" and "religious": (a) are ideologically biased and contradictory, although they are familiar to Western culture; and (b) that all attempts to set clear boundaries for these terms are logically inconsistent.

These critics have different views on the future of religious studies. Fitzgerald believes that religious studies should be replaced by cultural studies, since "the best work being produced in religious studies departments is not essentially any different from the work being done in departments of cultural studies or departments of cultural anthro-

2. See the website of The Critical Religion Association, accessed September 8, 2018, https://criticalreligion.org.

3. By ideology I mean the neutral conception of ideologies as "'systems of thought,' or 'systems of belief' or 'symbolic practices' which pertain to social action or political projects.” See Thompson 1984. 
pology" (Fitzgerald 2003). This position is radical, but it must be recognized that some areas of religious studies do face serious methodological problems. The most problematic field of religious studies is the psychology of religion.

In contrast to the sociology of religion, which remains close to its parent discipline of sociology, this discipline operates distant from the mainstream of psychological research (Paloutzian and Park 2005). There is one possible explanation for such a state of affairs: perhaps the methodology of this field is not good enough? Are the terms "religious feelings," "religious consciousness," and "religious psychotechniques" objective and measurable? To answer this question, I analyzed the leading research programs of modern psychology of religion using the "secular-religious" opposition: cognitive religious studies, neurotheology, and transpersonal psychology.

These intellectual projects define their objects of research in their own way. Neurotheology (Andrew Newberg, Moshe Idel) and transpersonal psychology (Abraham Maslow, Stanislav Grof, Evgeny Torchinov) study religious states/senses (See Arzy and Idel 2015; Maslow 1964; Atran 2004; Boyer 2007; Newberg and Waldman 2009; Torchinov 1998). They are interested in how people perceive space and their bodies, especially unusual cases. Cognitive religious studies (Pascal Boyer, Scott Atran) focus on religious beliefs/representations. This approach tries to understand why people believe in gods or paranormal phenomena. All three projects compete against and criticize each other (Pyysiäinen 2012, 123-25). I am interested in the research objectives of these paradigms and their application of the terms "religion" and "secularity."

\section{The study of religious states}

\subsection{Object of research}

The terms "religious states," "religious experience," "religious feelings," "mystical experience," and "transcendent experience" have plenty of meanings and contexts of use. I will focus on the interpretations that have been used to create objects of research in the psychology of religion.

Religious states are (a) any feelings experienced by a religious person; (b) senses constituting religiousness. The object of the study has a unique meaning only in the second case. 
Two opposite methodologies of "religious experience" compete in the psychology of religion: constructivism and essentialism. Essentialists believe that there are one or more types of mystical experience. They have a common nature, observable and reproducible, but described in different cultures differently. Constructivists believe that a universal mystical experience is impossible because such experience depends on cultural context and personal expectations. Each culture has its own special forms of experience, such as Hasidic Devekut or Buddhist Moksha, but they are completely different phenomena. There has been no consensus between the two sides since the 1970 s (Malevich 2013, 26-61). I will consider only essentialist scholars because no study of universal phenomena is possible within constructivism.

The American researcher Randall Studstill distinguishes five types of essentialism. Most of them have theological assumptions, therefore I am interested only in psychological essentialism, according to which mystical teachings and practices cause the same psychological transformations (Studstill 2005).

The model of psychological essentialism was proposed by Friedrich Schleiermacher in his Speeches on Religion. In his opinion, (1) religion is impossible without special psychological experience the feeling of unity with God; (2) dogmas and rituals are secondary derivatives of that feeling; (3) the ability to engage with religious experience is a natural ability of human psychology, which can be studied using the scientific method. Schleiermacher explained the details of this process in terms of the Kantian theory of knowledge (Shleiermakher 1994).

Next, I will consider six research projects on religious phenomena using the model of psychological essentialism. I will list the methods used to investigate "religious states" and then analyze their theoretical assumptions.

\subsection{Historical review of the methods of cognitive essentialism}

The first scientific attempts to connect religious experience with natural causes took place in the 1870 - 1890 s. Early psychologists William James in the USA and Jean-Martin Charcot in France were simultaneously interested in magnetism and spiritism and tried to explain their physiological nature. The psychologists Abraham Maslow and Stanislav Grof, and Buddhologist Yevgeny Torchinov, inspired by the intellectual tradition of psychoanalysis (Carl Jung) and the phenom- 
enology of religion (Mircea Eliade) were interested in the psychedelic movement of the 1960s. Andrew Newberg, an American neurotherapist, and Israeli scientists Moshe Idel and Shahar Arzy, used functional magnetic resonance imaging (fMRI) and electroencephalography (EEG) to describe brain processes during meditative or ecstatic practices in the 1990 s and 2000s.

1. Jean-Martin Charcot, one of the pioneers of neurology, spent thirty years studying neurological diseases at the Salpetriere clinic in Paris. In the 1880 os he conducted public experiments with hypnosis on patients with hysteria. Charcot suggested that the hysteria and ecstasy experienced by Christian saints are the same phenomenon as that experienced by his patients (Evans 2015). In 1893, in the article "Cure by Faith," he wrote:

Through all the ages, the most diverse civilizations, in the midst of religions apparently most dissimilar, the conditions of the miracle of healing have remained the same, its laws of evolution immutable.

I believe that the faith cure demands special subjects and special complaints - those, namely which are amenable to the influence of the mind over the body, if it is to find ground to work upon. Hysterical subjects offer a mental condition favorable to the operation of the faith cure (Charcot 1893).

2. William James collected dozens of testimonies from "religious geniuses" in his book The Varieties of Religious Experience and offered medical explanations of their conditions. According to his pragmatic philosophy, any human judgment (atheistic or religious) is "neurally conditioned," roughly speaking, it "depends on the liver" of the individual (James 1896). ${ }^{4}$ However, this fact does not diminish the value of these experiences for the individual and his or her moral life (James 1905). James tried to explain conversion or mystical insights by means of the rapid transition of preliminary thoughts into the focus of consciousness.

James not only documented the testimonies of "religious geniuses," but also experimented with nitrous oxide and recorded his impressions (James 1882). He also established the American branch of the Society for Psychical Research to study psychics and psychic phenomena. For fifteen years, he personally studied the psychic Leonora

4. "Is life worth living? It all depends on the liver." 
Piper, organized her public appearances, and claimed that she had extrasensory abilities (Fuller 2009).

3. In the 1960s, Stanislav Grof and Abraham Maslow founded the field of "transpersonal psychology." Maslow studied the phenomenon of self-development and tried to understand why happy people feel a selfless love for the world. He developed the concept of "peak experiences," that is, moments of the highest happiness and self-expression, feelings of love for being (B-love experience) like love, inspiration, aesthetic experience, and "mystical experience" (Maslow 1959).

Maslow suggested that peak experience is the core of all religions. This can be experienced by everyone, both atheists and priests. Previously, it had been "explained only in terms of the supernatural," but today such phenomena could be observed and evoked in experimental conditions by mean of psychedelics such as LSD. Maslow noted that "it looks as if these drugs often produce peak-experiences in the right people under the right circumstances, so that perhaps we needn't wait for them to occur by good fortune" (Maslow 1964).

This idea prompted Stanislav Grof to carry out experiments with psychedelics, and he summarized his results in The Adventure of Self-Discovery based on the testimony of his patients. He discerned three subconscious levels of the psyche: (1) biographical - psychological complexes or suppressed thoughts, (2) perinatal - the birth experience, and (3) transpersonal - going beyond consciousness, time, and space. Psychedelics and techniques like holotropic breathing make it possible to study the last two layers and lead to "the beginning of spiritual awakening." These "forms of spirituality" are similar to religions and the "worldview of great mystical traditions" (Grof 1994).

It is hard to call Grof's experiments scientific: introspective reports ceased to be a relevant psychological tool in the middle of the nineteenth century after Franz Brentano's criticism (Velichkovskii 1982, 46). The status of transpersonal psychology fluctuates between science and pseudoscience, and no one has conducted experiments with psychedelics except Grof and his followers.

However, Grof and Maslow's ideas became popular among religious scholars. In Russia, they were promoted by Buddhologist Evgeny Torchinov in his book The World Religions: Transcendental Experience. According to him, "the root of religious faith and religious life is transpersonal experience" (Torchinov 1998, 29). The experience itself is fundamentally indescribable, and therefore the catego- 
ries "God" and "supernatural" are only descriptive constructs. He argues that this experience is poorly examined in religious studies and scholars need to shift their focus from a sociological paradigm to a psychological one.

5 . The next attempt in the experimental study of religious experience emerged with the advent of neuroimaging technologies. In 1984, the first scientific work appeared in which the author explained the emergence of religion in terms of neuroscience; the term "neurotheology" was invented by Aldous Huxley in the 1962 novel The Island (Malevich 2013, 26-61).

Neurotheologists use MRI and EEG to track changes that occur in the brain during mystical states, and to understand how these states are induced. One of the most famous authors in this field is Andrew Newberg, professor of radiology and religious studies at the University of Pennsylvania.

Newberg carried out two kinds of research. In the first case, he searched for religious practitioners and asked them to perform their meditative (Franciscan sisters) or ecstatic (Pentecostals) practices. Then he studied changes in the subjects' brain activity during these rituals (N'iuberg and Uoldman 2013, 18-19).

In the second case, he asked random subjects who did not belong to any denomination to apply specific meditative practices for several weeks and measured brain activity before and after the practice. Newberg found that different types of meditation correlate with activation in different brain areas, but all of them positively affect attention, memory, and empathy. Patients had similar health improvements, regardless of whether they were atheists or belonged to any religion.

\section{The strong model}

Torchinov defines religion as (1) psychotechnics that introduce a person into (2) transpersonal and archetypal states, (3) triggering some subconscious mental mechanisms. In his model, the "religious" is connected only with the experience of transpersonal states; the rest is related to the "secular." For example, Confucianism is "civil rather than religious" and its rituals are similar to "the honors given to the national flag" (Torchinov 1998, 18).

Criticism. The strong model is based on the statement that transpersonal experience is possible only in religion, and in his book Torchinov considers only the practices of "world religions." But doesn't an 
atheist using "secular meditation" experience a transpersonal state? Torchinov unreasonably restricts transcendental experience within the framework of "religious" institutions, although it can be imagined outside of this circle.

\section{The moderate model}

This model is based on two assumptions. First, there are several extraordinary phenomena in the human psyche in which the world, body, and mind are perceived in an unusual way. They often occur in people with brain disorders, but any healthy person may experience them if they learn special practices or take drugs. In this case the success of the practice is independent of any beliefs.

1. Charcot: "Between religions and lay faith cures no distinction can be made; the same cause the same effect" (Charcot 1893).

2. Maslow: "Perhaps we can actually produce a private personal peak-experience under observation and whenever we wish under religious or nonreligious circumstances" (Maslow 1964, 17).

3. Newberg: "This was our first real evidence that a meditation practice, even when removed from its spiritual and religious framework, can substantially improve memory in people suffering from cognitive problems ... meditation can be separated from its spiritual roots" (Newberg and Waldman 2009, 31).

Second, the terms "God," "soul," "nirvana," and so on, are merely labels taken from ordinary language or the cultural environment for the expression of unusual experiences.

1. James: "The theories which Religion generates, being thus variable, are secondary"; "The faith state may hold a very minimum amount of intellectual content" (James 1905, 505).

2. Maslow: "Practically everything that happens in the peak-experiences, naturalistic though they are, could be listed under the headings of religious happenings, or indeed have been in the past considered to be only religious experiences" (Maslow 1964, 34).

3. Newberg: "If a survey only gives the respondent the choice of a few options, the result will come out black and white. Thus, we chose to give our survey participants free rein in describing their religious beliefs and spiritual experiences. Instead of coming up with a simple set of categories, we uncovered a rain- 
bow of colorful descriptions and beliefs" (Newberg and Waldman 2009, 10).

Criticism. According to the moderate model, meditative practices and drugs can change perception and consciousness, regardless of any interpretation of the nature of such phenomena. In this case, should such phenomena be called "religious" and do we need a special school of psychology to study them? The only justification for such a division is theological. It could be said that some meditative practices stimulate the brain, while others interact with the "divine." However, such assumptions are inappropriate for a scientific discipline with reproducible experiments.

\section{The weak model}

Idel and Arzy propose a model in which the terms "religious" and "secular" do not matter to the researcher at all. The only things that are important are techniques to achieve experience and the underlying mechanisms of consciousness. The interpretation of practitioners or different ideologies cannot reveal the nature of the phenomenon. The authors denote traditional approaches as top-down because they assess the content of the experience based on the cultural context. They call their own approach bottom-up and they aim to describe physiological correlates of mystical techniques with no axiological interpretation.

According to Arzy and Idel, the top-down approach simply exploits mystical experiences as material for studying other cultural phenomena. Such an approach is not suitable for studying mystical experience: the cultural and linguistic context distort the reports of mystics, because such experience is unusual and difficult to express. The leading ideologies usurp the right to interpret the experiences of mystics and usually avoid interpretations in which the "mystical object may not be the ultimate divinity but the mystic's self or body nonetheless" (Arzy and Idel 2013, 9). Finally, this approach overcomes cultural differences in the description of mystical practices. It assumes that mystical techniques evoke similar physiological processes in everyone (Arzy and Idel 2013, 10).

Criticism. The strong model is contradictory, and the moderate is absurd without theological assumptions. The weak model avoids the opposition of "religious" and "secular": it tends to understand general cognitive mechanisms in each mystical tradition. However, Idel and Arzy unwittingly continue to use these terms. 
Fig. 1. Three models of cognitive essentialism

Strong (Torchinov)

Mystical experience

Religion

Moderate (Charcot, James, Maslow, Grof, Newberg)

Mystical experience

Secular

Religion

Weak (Idel, Arzy)

Mystical experience

Any interpretation

is possible

\subsection{Discussion}

Almost all the authors reviewed here who use the words "religious" and "non-religious" admit that this division is deceptive or biased. This is the case because these terms are common in academic literature. According to Idel, "it is hard to avoid the pertinence of those approaches, formulated by intellectual prodigies, especially since they turned into conceptual tools that are part of the quotidian language" (Arzy and Idel 2013, 116).

The division of "religious/mystical experience" into three different phenomena could change this situation: (1) the perception of one's consciousness and body as distorted by mean of the techniques of meditation (Arzy and Idel 2013, 33); (2) strong positive feelings; and (3) intuitive theories about the causes of the first and the second. Those who have experienced such states often combine these phenomena, but they could and should be studied separately.

Alternative terminology for the first and second phenomena already exists in the academic literature. Neuroscience investigates various transpersonal states, such as autoscopy or dissociation, and positive psychology studies positive experience as "autotelic experience" or "flow" (Csikszentmihalyi 2011).

The third phenomenon causes more difficulty. It could be called "religion" or "spirituality," but such a designation links it to the theologies of the major confessions, although alternative interpretations are 
also possible. Therefore, a neutral terminology should be developed that will allow a clear description of people's experiences.

The paradigm of "intuitive theories" or "folk theories" could be the theoretical basis for such terminology (Gerstenberg and Tenenbaum 2017, 517-20). According to this theory, a person uses heuristics, simple rules that give quick but imperfect results, to solve complex everyday problems. These heuristics create intuitive theories about the causes of the surrounding phenomena and processes (Gelman and Legare 2011). They are often adequate to reality but lead to systematic errors where subtle calculations are required (Kahneman 2011, 84). At the same time, folk theories are very influential and serious efforts are required to change them.

I believe that the term "intuitive psychology" is appropriate for studying how a person interprets her transpersonal and autotelic experiences. In a narrow sense, it refers to the daily perception of other people as capable of thinking (Arico 2010, 372). In a broad sense, it describes "commonsense psychology that explains human behavior in terms of beliefs, desires, intentions, expectations, preferences, hopes, fears, and so on" (Baker 2001, 318), that is, intuitive assumptions about the nature of people's experiences, intentions, and estimations. Intuitive psychology applies to both individuals and groups. Theologies can be considered unique types of systematized folk psychology, created in historical circumstances by "theological guilds," or organized groups of intellectuals (Boyer 2007, 272).

\section{The study of religious beliefs}

The study of "religious representations" investigates the genesis of ideas about gods, higher powers, and other counterintuitive representations. The most popular and fruitful current research program for the study of such phenomena is Cognitive Religious Studies (CRS).

CRS studies the mechanisms of cognition and memory to explain the belief in the supernatural that occurs in all human cultures. The aim of the discipline is to solve a long-standing problem in religious studies: how to overcome the specific features of individual religions and prove that their positions are based on universal features of human cognition (Tremlin 2012).

Let us consider the most famous representatives of this approach, whose works have been published in the respected journals Science and Nature: French-American anthropologists Pascal Boyer and Scott 
Atran. The first conducted field research in Cameroon and Nepal, the second studied ISIS followers and the Druze (Atran 2010). I. Pyysiäinen calls them the creators of the "standard model" in CRS, and the books Religion Explained and In Gods We Trust are considered CRS "textbooks" (Pyysiäinen 2012, 123-25).

\subsection{Cognitive religious studies}

Cognitive religious studies is based on three theories: modularity of mind, slow and fast modes of thinking, and cultural evolutionism. The first theory encounters mind as a system of independent and specialized programs (Fordor 1985, 1-5). The second distinguishes between two modes of thinking: automatic thinking, which is quick and unconscious, and slow thinking, requiring cognitive load (Kahneman 2011). The third applies the laws of evolution to cultural selection, trying to explain the spread of beliefs and practices in human societies. It claims that the peculiarities of mind can explain why certain ideas are better remembered and more quickly disseminated than others (Boyd and Richerson 1988; Dawkins 1976; Sperber 1985).

In the 1980s, Atran applied these concepts in his study of folk biology, or the representation of the organic world by lay people (Atran 1998). Boyer investigated tale transmission in African tribes and the use of theological concepts in everyday speech (Barrett 1999). At the end of the 9os, both scientists began to study "religious concepts."

The standard model of CRS consists of the following premises:

\section{The specificity of "religion"}

Atran and Boyer argue that the term "religion" is problematic, but it can be used in scientific research:

1. Atran: "Religion is a fuzzy category with no transparent distinction between beliefs or actions as religious or not. Nevertheless, readily identifiable clusters of empirically and logically inscrutable beliefs reoccur cross-culturally as a by-product of nonreligious cognitive functions evolved for mundane purposes" (Atran and Ginges 2012, 855-57).

2. Boyer: "Religion" is "a common prescientific category that may need to be replaced with other, causally grounded, scientific categories," which help us to understand human cognition (Boyer and Bergstrom 2008). 
Therefore, in CRS religious beliefs and secular ideology are clearly divided. Religious or supernatural concepts are those notions that: (1) are invisible and have intentions; and (2) evoke emotions and action.

1. Atran: "Faith in religious beliefs rests not on logical coherence and empirical evidence but is sustained by costly rituals whose elements may have no active or useful relationships in everyday life" (Atran and Ginges 2012).

2. Boyer: "Religious concepts are those supernatural concepts that matter. . . [they] can induce strong feelings of fear, guilt, anger but also reassurance or comfort" (Boyer 2007, 137).

In order to avoid Abrahamic notions of God and include such phenomena as the belief in aliens, spirits, ghosts, and so on, the authors defined "religion" as broadly as possible.

\section{The naturalness of religion}

There is no special religious organ/department of the brain or religious specialists, those who perceive religious agents better than others. Religious notions arise as a by-product of the most common cognitive mechanisms, such as memory, attention, abstract thinking, and emotional intelligence. Boyer stresses that these abilities are the same for all people, otherwise religious geniuses would not be understood (Boyer 2007, 309).

\section{Why religious beliefs are easily remembered and af- fect people}

Human thinking constantly produces spontaneous guesses about the world, but only a small number of them are culturally successful, that is, they remain in memory and are transferred to other people. Religious notions arise in all cultures, are passed down from generation to generation, and influence human behavior. Their cultural survival is caused by two factors.

(1) Memory advantage. Some stimuli are more conspicuous and better consolidate in long-term memory than others. Experiments demonstrate that "minimally counterintuitive concepts" evoke such an effect. They violate "assumptions about the basic categories of existence" and cause fascination. An optimal number of counterintuitive elements (2.5) within a tale makes it interesting to narrate and guarantee its stability during transmission (Norenzayan et al. 2006). 
(2) Relevance. Representations that provoke action matter more than those that do not. For example, an intelligent but bodyless being causes fascination, however, it becomes relevant only if it knows something about our past and future and could be harmful or protective. According to Atran, "costly and seemingly arbitrary ritual commitment to apparently absurd beliefs deepens trust, galvanizing group solidarity for common defense and blinding members to exit strategies." He demonstrates in numerous examples that religious groups are very cooperative, but prone to conflict in defending their "sacred values" (Atran and Ginges 2012).

\subsection{The cognitive religious studies research program}

For CRS, both criteria of religious beliefs are essential: (1) counterintuitiveness; and (2) the ability to evoke emotions and provoke behavior. If we consider only the first criteria, then "the Mickey Mouse problem" arises: what is the difference between religious doctrine and fairy tale? If only the second, then the "the Marx problem" occurs: how do religions differ from ideologies?

Atran: Cognitive theories of religion are motiveless. They cannot, in principle, distinguish Mickey Mouse and the Magic Mountain from Jesus and the burning bush, fantasy from religious belief. . . Commitment theories are mindblind. For the most part, they ignore or misrepresent the cognitive structure of the mind and its causal role. They cannot in principle distinguish Marxism from monotheism, ideology from religious belief. (Atran 2004, 14)

To solve the first problem, cognitive religious scholars have developed criteria for distinguishing fairy tales from religion. Justin Barrett highlights five attributes of "god concepts": they are counterintuitive, violate intuitive assumptions about some ontological categories, they are intentional agents, they possess strategic information (about life, death, love, and honesty), and their acts are detectable in the human world and motivate human behaviors. These criteria explain why we do not consider Mickey Mouse (who does not affect the world) and George W. Bush (who is not counterintuitive) to be gods (Barrett 2008).

2. "The Marx problem" is harder to solve. Marxism, Confucianism, the secular cult of the French Revolution, "market fundamentalism," and so on have the same properties mentioned by Barrett. For example, the laws of history in Marxism are paradoxical (it is not clear how 
the laws of history exist), relate to strategic phenomena (the distribution of wealth), are detectable, evoke powerful feelings, and inspire actions. In public rituals, "an abstraction like 'our tradition' or 'society' can play much the same role as gods or ancestors" (Boyer 2007, 262).

Atran admits that "supernatural entities" occur both in religions and "in political and economic ideologies." However, ideological entities are non-intentional, have no consciousness and goals, and no personal emotional connections can be established with them (Atran 2004, 15). Therefore, religious beliefs and rituals are more successful in strengthening group cohesiveness than secular ones. Atran believes that someday "neuroimaging may elucidate how religion and sacred values differ from secular beliefs and values" (Atran and Ginges 2012).

3. In solving these problems, Atran involuntarily creates new ones:

(1) The case of Buddhism. There are many non-theological religions in which deities or supreme principles are unintentional.

(2) The case of Wahhabism. There are many religious teachings prohibiting any anthropomorphic description of gods, especially any suggestion about their direct interference in human affairs.

CRS could answer that concepts elaborated by theological experts are not the same as intuitive representations of gods. However, the same argument could be applied to secular ideologies, and then we face...

(3) The case of nationalism. Atran claims that after the Westphalian peace secular national states were instituted and wars on religions ended. The ideology of these states lacks concepts of anthropomorphic and intentional supernatural beings and they do not consider their values as absolute. Perhaps humanism, nationalism, Marxism, and so on, in their doctrinal forms, are indeed prone to compromise and do not ensoul such concepts as "nation," "history," "human rights," and so on. However, it is easy to prove that these abstract entities often became animated, sacralized, and evoke conflicts.

First, in social isolation or grave danger humans are prone to anthropomorphize nonhuman agents (puppets or computer gadgets) (Epley et al. 2008). Nation, traditions, and culture also could be easily personalized. A large body of research exists about the representation of the nation as a woman or a man (see Riabov 2008; Weaver 2002; McClintock 1995), a sovereign body (Kantorowitz 1957), an animal, et cetera. ${ }^{5}$

5. It is not clear why totemism is usually described in research literature as religion, but not as national symbol. 
Second, it is arguable that religious communities are more cohesive than secular ones. Atran forgets about secular armies demonstrating excellent discipline and organization. During their history people have fought for their nation, tradition, ancestors, and other abstract, invisible entities, doing so altruistically, out of love for their sacred symbols. As Benedict Anderson writes, "for most ordinary people of whatever class the whole point of the nation is that it is interestless" (Anderson 2006, 144).

Finally, Atran acknowledges that any values can be made sacred and that any ideology can use rituals and absurd beliefs to strengthen group solidarity:

1. "Sacred values are not exclusive to religion; mundane values may be sacralized through rituals linking them to nonreligious sacred values, like the nation."

2. "Thus, even ostensibly secular nations and transnational movements usually contain important quasi-religious rituals and beliefs: from sacred songs and ceremonies, to postulations that providence or nature bestow equal rights" (Atran and Ginges 2012).

Fig. 2. Atran and Boyer's model of cognitive religious studies

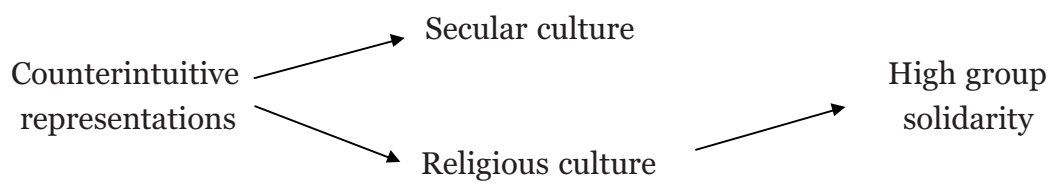

\subsection{Discussion}

CRS's attempt to separate secular and religious concepts is problematic. First, Atran and Boyer admit that (1) religious notions have no specific content or origin; (2) only their intentionality distinguishes them from secular concepts. However, psychological experiments and historical examples demonstrating the rapid humanization of objects and representations disprove this statement. Then the authors try to prove that religious ideas strengthen group solidarity more than secular ones. However, national symbols also evoke strong feelings and increase group solidarity, while national satisfaction improves subjective well-being (Morrison et al. 2011). If we draw an arrow from "secular culture" to "solidarity" in the above model (see fig. 2), then the dichotomy of secular and religious becomes useless. 
This confusion is caused by two factors. First, European culture is biased in its contrast of secular ideologies and religions. The latter are perceived as more violent, less negotiable, and less rational (Cavanaugh 2009, 7). Second, Atran and Boyer decided that sacralization and counterintuitiveness are particular only to religions. However, plenty of research undermines this statement.

A research subject such as "religious beliefs" should be divided into two components: sacralization and counterintuitiveness. Prerequisites for the study of sacralization already exist in social psychology, like the theory of protected values developed by Jonathan Baron: these are values "that resist trade-offs with other values, particularly economic values" (Baron and Spranca 1997). The focus here shifts from the religious/secular opposition to the economic/ moral dichotomy. Baron's students investigate mundane phenomena such as resistance to biotechnology (Scott et al. 2016). Cognitivists and cultural evolutionists investigate counterintuitive representations (supernaturalism) and their role in the transmission of ideas in societies.

Perhaps protected values and counterintuitive representations have an interactive effect. But we should not assign them only to those cultural spheres that we call "religious," ignoring the spheres that we call "secular." Neuroimaging may never elucidate the difference between sacred and secular because this distinction remains merely because of centuries-old habit.

\section{Conclusion}

I examined two paradigms of the psychology of religion and the objects of their research. Neurotheology and transpersonal psychology construct their objects by referring to altered states of consciousness, CRS by referring to religious beliefs. In both cases, the disciplines blended physiological processes and their interpretation, ignored secular phenomena, and provided no advantage for scientific research. The only field properly using this dichotomy is theology, but this subject is very far from psychology, which is experimental and reproducible.

A research program in the psychology of religion has resources to elaborate a new "protective belt of hypothesis" (Lakatos 1976). Various theories can disguise or partly solve problems that undermine the core explicit assumption of religious essentialism, that is an existence of unique and scientifically explorable realm of religion. An 
alternative approach should be developed to make it possible to completely avoid the "religious-secular" dichotomy. I proposed two features of such an alternative program: (a) altered states of consciousness and their intuitive interpretations, as well as sacred values, and counterintuitive representations ought to be studied separately; and (b) they should not be distinguished as "secular" and "religious." I propose another paradigm: there is no essential "religious" domain, either as an observable psychological state, or as a unique system of beliefs.

Regardless of the acceptance of this proposal by the scientific community, attention needs to be paid to this problem. Moreover, the methodology of other research projects, such as the sociology of religion, should be questioned.

\section{References}

Anderson, Benedict. 2006. Imagined Communities: Reflections on the Origin and Spread of Nationalism. New York: Verso.

Arico, Adam. 2010. "Folk Psychology, Consciousness, and Context Effects." Review of Philosophy and Psychology 1(3): 371-93.

Arinin, E. 2013. Chto takoe religia: 500 opredelenii termina s kommentariami [What religion is: 500 definitions with commentaries]. Vladimir: VSU.

Arzy, Shahar, and Moshe Idel. 2015. Kabbalah: A Neurocognitive Approach to Mystical Experiences. New Haven: Yale University Press.

Asad, Talal. 2003. "Islam, Secularism and the Modern State: Talal Asad Discusses His Work on Secularism in the Modern World.” Asiasociety.org. Accessed December 3, 2017, http://asiasociety.org/islam-secularism-and-modern-state.

Atran, Scott. 1998. "Folk Biology and the Anthropology of Science: Cognitive Universals and Cultural Particulars." Behavioral and Brain Sciences 21(4): 547-69.

---. 2004. In Gods We Trust: The Evolutionary Landscape of Religion. Oxford: Oxford University Press.

---. 2010. Talking to the Enemy: Faith, Brotherhood, and the (Un)Making of Terrorists. N.p.: Harper Collins.

Atran, Scott, and Jeremy Ginges. 2012. "Religious and Sacred Imperatives in Human Conflict.” Science 336(6083): 855-57.

Baker, L. 2001. "Folk Psychology." In The MIT Encyclopedia of the Cognitive Sciences. Cambridge, MA: MIT Press.

Baron, Jonathan, and Mark Spranca. 1997. "Protected Values.” Organizational Behavior and Human Decision Processes 70(1): 1-16.

Barrett, Justin. 1999. "Theological Correctness: Cognitive Constraint and the Study of Religion." Method \& Theory in the Study of Religion 11(4): 325-39.

--_. 2008. "Why Santa Claus Is Not A God." Journal of Cognition and Culture 8(1-2): 149-61.

Boyd, Robert, and Peter J. Richerson. 1988. Culture and the Evolutionary Process. Chicago: University of Chicago Press. 
Boyer, Pascal. 2007. Religion Explained: The Evolutionary Origins of Religious Thought. New York: Basic Books.

--_. 2008. "Being Human: Religion: Bound to Believe?” Nature 455(7216): 1038-39.

Boyer, Pascal, and Brian Bergstrom. 2008. "Evolutionary Perspectives on Religion.” Annual Review of Anthropology 37: 111-30.

Cahill, Lisa. 2012. Review of Myth of Religious Violence: Secular Ideology and the Roots of Modern Conflict. Modern Theology 28(3): 561-63.

Cavanaugh, William. 2009. The Myth of Religious Violence: Secular Ideology and the Roots of Modern Conflict. Oxford: Oxford University Press.

-- . 2011a. "The Invention of Fanaticism." Modern Theology 27(2): 226-37.

-—-. 2011b. "Religious Violence as Folklore.” Religion and Society 2: 122-27.

-_-. 2013. "The Root of Evil: Does Religion Promote Violence?” America 209(3): 11(4).

Charcot, J.M. 1893. "The Faith Cure.” The New Review 8(44): 18-31.

Csikszentmihalyi, Mihaly. 2011. Potok: Psikhologiia optimal'nogo perezhivaniia [Flow: A psychology of optimal experience]. Moscow: Alpina.

Dawkins, Richard. 1976. The Selfish Gene. New York: Oxford University Press.

Epley, N., S. Akalis, A. Waytz, and J. Cacioppo. 2008. "Creating Social Connection through Inferential Reproduction: Loneliness and Perceived Agency in Gadgets, Gods, and Greyhounds.” Psychological Science 19(2): 114-20.

Evans, Jules. 2015. "Jean-Martin Charcot and the Pathologization of Ecstacy.” The History of Emotions Blog. Accessed May 31, 2018, https://emotionsblog.history.qmul.ac. uk/2015/o3/jean-martin-charcot-and-the-pathologization-of-ecstasy/.

Fitzgerald, Timothy. 2003. The Ideology of Religious Studies. New York: Oxford University Press.

Fodor, Jerry. 1985. "Precis of the Modularity of Mind." Behavioral and Brain Sciences 8(1) (March): 1-5.

"Forum: Antropologiia Religii" [Forum: The anthropology of religion]. 2017. Antropologicheskii Forum 34.

Fuller, Robert. 2009. Wonder: From Emotion to Spirituality. Chapel Hill: University of North Carolina Press.

Gelman, Susan, and Cristine Legare. 2011. "Concepts and Folk Theories.” Annual Review of Anthropology 40: 379-98.

Gerstenberg, Tobias, and Joshua Tenenbaum. 2017. "Intuitive Theories." In Oxford Handbook of Causal Reasoning, edited by Michael Waldmann, 515-48. New York: Oxford University Press.

Grof, Stanislav. 1994. Puteshestvie $v$ poiskakh sebia [The adventure of self-discovery]. Moscow: Izdatel'stvo Transpersonal'nogo Instituta.

James, William. 1882. "Subjective Effects of Nitrous Oxide." Mind 7.

---.1896. Is Life Worth Living? Philadelphia: S. Burns Weston.

- - . 1905. The Varieties of Religious Experience: A Study in Human Nature. New York: Longmans, Green, and Co.

Kahneman, Daniel. 2011. Thinking, Fast and Slow. London: Penguin.

Kantorowicz, Ernst H. 1957. The King's Two Bodies: A Study in Medieval Political Theology. Princeton, NJ: Princeton University Press.

Keen, Sam. 1986. Faces of the Enemy: Reflections of the Hostile Imagination. San Francisco: Harper \& Row. 
Kenny, Celia. 2014. "Law and the Art of Defining Religion." Eccesiastical Law Journal 16(1): $18-31$.

Lakatos, Imre. 1976. "Falsification and the Methodology of Scientific Research Programmes." In Can Theories Be Refuted?: Essays on the Duhem-Quine Thesis, edited by Sandra G. Harding, 205-59. Dordrecht: Springer.

Malevich, T.V. 2012. "Neiroteologiia: Teorii religii i nauka o mozge" [Neurotheology: Theories of religion and brain studies]. In Religiovedcheskie issledovaniia (1-2): 6283 .

---. 2013. "Filosofiia religii o misticheskom opyte: Dilemma essentsializma i konstruktivizma." In Filosofiia religii: Al'manakh [Philosophy of religion about mystical experience: The dilemma of essentialism and constructivism." In Philosophy of Religion: Almanac], 26-61. Moscow: Nauka.

Maslow, Abraham. 1959. "Cognition of Being in the Peak Experiences.” The Journal of Genetic Psychology 94(1): 43-66.

---. 1964. Religions, Values, and Peak-Experiences. Columbus: Ohio State University Press.

McClintock, Anne. 1995. Imperial Leather: Race, Gender, and Sexuality in the Colonial Conquest. New York: Routledge.

Morrison, Mike, Louis Tay, Ed Diener. 2011. "Subjective Well-Being and National Satisfaction: Findings from a Worldwide Survey.” Psychological Science 22(2): 166-71.

Newberg, Andrew. 2010. Principles of Neurotheology. Burlington, VT: Ashgate Publishing.

Newberg, Andrew, and Mark Waldman. 2009. How God Changes Your Brain: Breakthrough Findings from a Leading Neuroscientist. New York: Ballantine.

Newman, L. 1998. "Znachenie metodologii: Tri osnovnykh podkhoda" [The meaning of methodology: Three basic approaches]. Sociologicheskie issledovania 3: 122-34.

Norenzayan, Ara, Scott Atran, Jason Faulkner, and Mark Schaller. 2006. "Memory and Mystery: The Cultural Selection of Minimally Counterintuitive Narratives.” Cognitive Science 30(3): 531-53.

Paloutzian, Raymond F., and Crystal L. Park. 2005. "Integrative Themes in the Current Science of the Psychology of Religion." In Handbook of the Psychology of Religion and Spirituality, 3-20. 2nd edition. New York: Guilford Press.

Pyysiäinen, I. 2012. "Kognitivnoe religiovedenie kak issledovatel'skaia programma” [Cognitive religious studies as research project]. Religiovedcheskie issledovania 1-2: $123-25$.

Riabov, O. 2017. "Rossiia-Matushka": Natsionalizm, gender, voina $v$ Rossii XX veka ["Mother Russia": Nationalism, gender, war in 2oth-century Russia]. Stuttgart: Ibidem Verlag.

Shleiermakher, F. [Friedrich Schleiermacher]. 1994. Rechi o religii [Speeches on religion]. Moscow: Aleteia.

Sperber, Dan. 1985. "Anthropology and Psychology: Towards an Epidemiology of Representations." Man 20(1): 73-89.

Strenski, Ivan. 2004. "Ideological Critique in the Study of Religion: Real Thinkers, Real Contexts, and a Little Humility." In New Approaches to the Study of Religion, edited by P. Antes, A.W. Geertz, and R.R. Warne, 271-94. Berlin: Walter de Gruyter.

Studstill, Randall. 2005. The Unity of Mystical Traditions: The Transformation of Consciousness in Tibetan and German Mysticism. Leiden: Brill.

Thompson, John B. 1984. Studies in the Theory of Ideology. Berkeley: University of California Press. 
Torchinov, E. 1998. Religii mira: Opyt zapredel'nogo; Psikhotekhnika i transpersonal'nye sostoianiia [The world religions: Transcendental experience; Psychotechnique and transpersonal states]. St. Petersburg: Tsentr "Peterburgskoe Vostokovedenie."

Tremlin, T. 2012. "Kognitivnyi i sravnitel'nyi podhody: Kak novoe kognitivnoe religiovedenie mozhet pomoch' sravnitel'nomu religiovedeniiu?” [Cognitive and comparative approaches: How the first may help to the second]. Researches in Religious Studies $7-8$.

Uzlaner, D.A. 2008. "Raskoldovyvanie diskursa: 'Religioznoe' i 'svetskoe' v iazyke novogo vremeni" [Disenchantment of discourse: "Religious" and "secular" in the language of modernity]. Logos 4: 140-61.

Velichkovskii, B.M. 1982. Sovremennaia kognitivnaia psikhologïa [Contemporary cognitive psychology]. Moscow: MSU.

Weaver, E. 2002. "Madonna Crucified: A Semiotics of Motherland Imagery in Hungary." Slovo 14: 54-76.

Zinnbauer, Brian, and Kenneth Pargament. 2005. "Religiousness and Spirituality.” In Handbook of the Psychology of Religion and Spirituality, edited by Raymond F. Paloutzian and Crystal F. Park, 21-42. 2nd edition. New York: Guilford Press. 